mag. Nadja

Dobnik

Ekonomska fakulteta v Ljubljani

\section{PROGRAMIRANJE V JEZIKOVNEM IZOBRAŽEVANJU ODRASLIH}

\section{Vsebina programa kot dogovor med izobraževalcem in udeleženci izobraževanja}

0 draslim kot posebni ciljni populaciji v jezikovnem izobraževanju šele v zadnjih desetletjih posvečamo več pozornosti. Še vedno je močno zakoreninjeno mnenje, da se odrasli tujih jezikov ne morejo učiti tako uspešno kot otroci, podobno kot je še vedno pogost tudi predsodek, da gre učenje otrokom lažje od rok kot odraslim. Ker so bili odrasli dolgo odrinjeni na rob organiziranih oblik vzgoje in izobraževanja, smo tudi na področju učenja tujih jezikov največ pozornosti posvečali otrokom. To je povezano tudi s tem, da večina

Učenju tujih jezikov pri odraslih namenjamo še vedno premalo pozornosti. institucionaliziranega učenja tujih jezikov poteka $v$ šolah. $\mathrm{Na}$ druge formalne in neformalne oblike učenja tujih jezikov (tudi pri mladih) pa se še danes marsikje gleda zadrŽano in podcenjujoče ne glede na to, ali dajejo boljše učne uspehe kot formalne oblike.

Dogaja se, da nekdo, ki se dobro sporazumeva $v$ tujem jeziku in ga za to pohvalite, odmahne z roko: »No, malo se že zmenim, ampak učil se nisem nikoli.« Pomanjkanje prave predstave o lastnem znanju in s tem povezano nezaupanje $v$ lastno znanje sta pogosto posledica pomanjkanja primerne povratne informacije ali pripisovanja prevelikega pomena formalnemu izobraževanju. Neformalnega izobraževanja navadno ne vrednotimo, uspehov ne merimo, zato je tudi priznanj manj.

\section{SPOSOBNOSTI ODRASLIH ZA UČENJE TUJIH JEZIKOV}

Uveljavljanje andragogike kot samostojne vede je $\mathrm{v}$ marsičem povezano tudi $\mathrm{z}$ učenjem tujih jezikov. Eden prvih avtorjev, ki so pomembno pripomogli $\mathrm{k}$ razumevanju dejanskih sposobnosti odraslih za učenje, je Edward Thorndike, ki je s svojimi raziskavami o sposobnostih odraslih za učenje prvi znanstveno ovrgel predsodek, da so sposobnosti odraslih za učenje slabše od sposobnosti otrok. Med drugim je dokazal tudi to, da se odrasli učinkoviteje učijo tujega jezika kot otroci, če se učijo na sebi primeren način, in ne $\mathrm{z}$ mehaničnim posnemanjem. Eksperiment, ki ga je naredil z esperantom kot nevtralnim jezikom, je pokazal, da so se odrasli dva- ali večkrat hitreje učili esperanta kot otroci, stari od deset do osemnajst let. Obenem je dokazal, da znanja otrok ne moremo meriti enako in $\mathrm{z}$ istimi instrumenti kot znanje odraslih. Pri mlajših so testi znanja pokazali boljšo sposobnost reprodukcije mehanično pridobljenega znanja, odrasli pa so bili neprimerno uspešnejši pri bolj kompleksnih na- 
logah, Ti na podlagi asociacij $\mathrm{z}$ drugim znanjem in izkušnjami hitreje osvojijo tudi kompleksnejše stavčne tvorbe in besedne zveze ter druge zahtevnejše segmente jezika, otroci pa se pri učenju tujega jezika zanašajo predvsem na intuicijo in neposredno posnemanje (Krajnc, 1979-b, str. 49).

Odrasli so navadno res manj uspešni v naivnem, spontanem osvajanju tujega jezika, je pa zelo zmotno misliti, da imajo slabše sposobnosti učenja pri sistematskem pouku. Po Lennebergovi biološki teoriji jezika (Lenneberg, 1967) poteka primarno osvajanje jezika med 2., 3. letom in puberteto s prepletanjem dozorevanja ter samoprogramiranega učenja. Lenneberg trdi, da ima človek prirojen "mehanizem « za učenje jezikov, ki so ga kasneje poimenovali LAD - »language acquisition device«. Po puberteti pa sposobnost samoorganiziranosti in prilagajanja psihološkim zahtevam verbalnega vedenja naglo upada. Pomen Lennebergove teorije za učenje tujih jezikov je v ugotovitvi, da do pubertete otroku njegova prirojena sposobnost učenja jezika omogoča, da sam strukturira tuji jezik, ki se ga uči, po puberteti (na primer $v$ izobraževanju odraslih) pa ta prirojena sposobnost učenja jezika upade in zato odrasel učenec potrebuje bolj strukturiran pristop $\mathrm{k}$ učenju tujega jezika in več obrazložitev njegovih zakonitosti. Po Lennebergovi teoriji tudi ni pomembno, da primerjamo način, kako se otrok uči maternega jezika, $\mathrm{z}$ načinom, kako se človek po puberteti uči tujega jezika. Zato je treba narediti razliko med različnim pristopom $\mathrm{k}$ učenju in poučevanju jezika v različnih življenjskih obdobjih. Prav te razlike pa literatura ne poudarja dovolj. Različni vidiki Lennebergove teorije so doživeli številne odzive in so bili izhodišče ter izziv za številne raziskovalce, $v$ svojih osnovnih ugotovitvah pa je. teorija pomemben prispevek $\mathrm{k}$ razmišljanju o načinu učenja tujih jezikov pri otrocih in odraslih.
Dejstvo je, da ima odrasla oseba določene sposobnosti, ki podpirajo učenje tujega jezi$\mathrm{ka}$, in da jih otrok še nima. Fedora Umek (Umek, 1979, str, 22-23) poudarja:

- odrasli nikdar ne izgubi izpred oči ciljev, zaradi katerih se uči, kar pomeni, da je za učenje stalno motiviran ne glede na to, za kakšno vrsto motiviranosti gre (bodisi utilitaristično-instrumentalno, pri čemer želi znati jezik, ker si od tega obeta koristi, bodisi idealistično-integrativno zaradi želje po širši izobrazbi, boljšem vpogledu v tujo kulturo, razvijanju lastne osebnosti ipd; pri tem je treba omeniti tudi motiviranost, ki izvira iz zanimanja za jezik, značilnega za lingviste);

- včasih sam doume cilje posamezne sekvence $\mathrm{v}$ učni stopnji, če pa ne, je sprejem-

Odrasli zahtevajo
strukturiran
pristop k učenju
tujega jezika.
ljiv za obrazložitev in se je pripravljen potruditi pri delu, ki samo na sebi ni zanimivo;

- mnogo bolj kot otrok ali mladostnik je sposoben analitičnega in deduktivnega mišljenja;

- ima mnogo boljši spomin zaradi asociacij in osmišljanja - znano je, da se otrok tujega jezika nauči presenetljivo hitro, da pa ga hitreje pozabi, če nima več stika z njim.

Bolj ko je učenje tujega jezika vpeto $v$ posameznikovo življenje, počasnejše je pozabljanje. Potrebe in interesi odraslega po znanju tujega jezika izhajajo iz konkretnih življenjskih okoliščin, zato se uči s predstavo o tem, kje in kako bo pridobljeno znanje tudi uporabil, in išče potrditev svojega znanja $\mathrm{v}$ uporabi. Otroci se učijo tujega jezika zaradi učenja ter predvsem skozi igro in imajo redko pred očmi konkreten cilj, odrasli pa imajo cilj stalno pred očmi. Če se učenje jezika preveč oddalji od ciljev, ki so si jih zastavili, lahko motivacija hitro upade, saj v svoji dejavnosti ne bodo 
več našli prave potrditve in pravega smisla. Načrtovanje jezikovnega izobraževanja mora zato izhajati iz predstav, pričakovanj, potreb in interesov udeležencev. Koliko jih bo mogoče upoštevati $v$ fazi programiranja vsebin in koliko bo izobraževalec program dopolnjeval tudi pozneje, je odvisno od okoliščin, v katerem potekata načrtovanje in izvedba izobraževanja. Nikoli pa nastajanje in izvedba programa ne moreta potekati brez predstave $o$ tem, kakšne so potrebe, interesi in pričakovanja udeležencev.

\section{POSEBNOSTI PROGRAMIRANJA V JEZIKOVNEM IZOBRAŽEVANJU}

Andragogika opredeljuje programiranje kot tisto fazo $v$ pripravi izobraževalnih programov, v kateri se opredelijo vsebine programa. Izhodišče za izbiro in oblikovanje vsebin je ciljna skupina oziroma njene potrebe, izražene v ciljih, ki jih mora izobraževanje doseči. Programiranje torej zadeva vsebinski del izobraževanja, $\mathrm{z}$ metodičnim delom pa se ukvarja planiranje, pri katerem gre za iskanje najprimernejše oblike izobraževanja, virov in metod dela, torej za vprašanje, v kakšni obliki in kako je jezikovno znanje posredovano slušatelju. S cilji, vsebinami in metodami so po-

Že hiter vpogled v zgodovino jezikovnega izobraževanja nam pokaže, da je bilo poučevanje tujih jezikov povezano predvsem $\mathrm{z}$ vprašanjem metode. To dokazuje že samo imenovanje večine pristopov k poučevanju tujih jezikov; slovnično-prevajalna metoda, avdiolingvalna metoda, direktna metoda, situacijska metoda ipd. Močan poudarek je bil na vprašanju, kateri je pravi način, katera je prava, »čudežna« metoda, po kateri bi se večina ljudi ali celo vsi lahko uspešno učili tujih jezikov. »Metode so, kljub terminološki nedoslednosti pri njihovem poimenovanju in mestoma slabi zgodovinski dokumentiranosti, najvidnejši in najvplivnejši parameter jezikovnega poučevanja in s tem tudi učbenikov. (Skela, 1998, str. 51) Vprašanje vsebin je bilo v ozadju, z njim se avtorji do sedemdesetih let 20 . stoletja ekplicitno pravzaprav niso ukvarjali. vezani tudi postopki vrednotenja, ki so dejansko vpeti v vse faze učenja tujega jezika: od faze ugotavljanja potreb, pri čemer je treba oceniti predznanje slušatelja, do postopkov, s katerimi slušatelj dobiva povratno informacijo o pridobljenem znanju.

Razlogov za to je več. V prvi vrsti gre za to, da je zgodovina jezikovnega poučevanja zgodovina formalnega, uradno priznanega jezikovnega poučevanja. To je v prejšnjih stoletjih potekalo $v$ okviru šole in šolskega sistema, ta pa je temeljil na poučevanju tujih jezikov za potrebe, ki so jih imeli izobraženi sloji: branje, interpretacija in prevajanje znanstvenih ter literarnih besedil (slovnično-prevajalna metoda). Pouk je potekal po učnem načrtu, ki je bil že izdelan, po učbeniku, ki je bil predpisan. Učitelj je imel zanemarljiv vpliv na vsebino, saj so šolske oblasti natančno določile, kaj morajo slušatelji znati in káko bo njihovo znanje ocenjevano. Reakcijo na slovnično-prevajalno metodo poučevanja so narekovale spremembe družbenih, ekonomskih, socialnih razmer (zaradi vedno večje mobilnosti so ljudje potrebovali znanje pogovornega jezika, dostop do izobraževanja se je začel odpirati za vedno širše sloje prebivalstva itd.) in tudi dognanja na področju psihologije ter lingvistike. Predvsem pa je poučevanje tujih jezikov tudi že preseglo okvire šlskega sistema. Odrasli so se lahko tujih jezikov organizirano učili tudi v jezikovnih šolah in centrih, ki so smeli poučevati po lastnih metodah.

Vendar so vprašanja, povezana z vsebinami, kljub novim usmeritvam na področju jezikovnega izobraževanja še naprej ostala v ozadju. To je povezano s še enim pomembnim dejstvom oziroma $\mathrm{z}$ vlogo, ki jo ima $\mathrm{v}$ jezikovnem izobraževanju učbenik. Jezikovnega poučevanja na začetnih stopnjah si namreč ni mogoče zamisliti brez učnega gradiva, ki ga praviloma sestavljajo učbenik, delovni zvezek in zvočni posnetki. Za razvijanje sposob- 
nosti pisnega razumevanja in izražanja so potrebna besedila in vaje, za razvijanje sposobnosti slušnega razumevanja pa avdio- in videoposnetki. Vendar je pisanje študijskega gradiva in priprava avdio-vizualnih dokumentov zelo zahtevno in kompleksno delo, ki zahteva veliko časa in tudi veliko sredstev. Še v preteklih desetletjih so si pisanje učbenikov in snemanje avdiokaset lahko privoščili le veliki jezikovni centri in inštituti, večinoma v sodelovanju $\mathrm{z}$ založbami in produkcijskimi hišami (na primer CREDIF, BBC, Oxford University Press, Goethe Institut, Langenscheidt). Zato je razumljivo, da je bilo vprašanje vsebin tudi za mentorje $v$ jezikovnih šolah za odrasle pravzaprav nepomembno, saj so bili prisiljeni izbrati med razpoložljivimi učbeniki in poučevati na podlagi koncepta vsebin, ki so ga pripravili avtorji učbenika.

Skoraj ves manevrski prostor, ki ga je imel nekoč učitelj, je bil omejen na metode poučevanja, iskanje načinov in tehnik, $\mathrm{s}$ katerimi bi bilo vsebine učbenika mogoče čim učinkoviteje posredovati študentom. Zato je razumljivo, da učitelji tujih jezikov niso razvijali odnosa do programiranja. To se kot pristop $k$ poučevanju tujih jezikov pozna še danes: pogosto namreč učitelji enačijo vsebino učbenika z vsebino programa oziroma prilagodijo program in cilje poučevanja vsebinam učbenika. Tak pristop je seveda napačen, saj je lahko učbenik - še tako dober - le pripomoček s funkcijo koncepta ciljev in vsebin, ki si jih je mentor zastavil glede na potrebe določene ciljne skupine.

Pomen učbenika v jezikovnem izobraževanju odraslih se je v zadnjem desetletju že začel zmanjševati, saj vse večje število učbenikov, vadnic, multimedijskih paketov in podobnih gradiv mentorju omogoča čedalje večjo izbiro in možnost kombiniranja različnih virov. Bistveno vlogo pri tem je imel tudi napredek tehnologije, ki mentorju omogoča, da sam pripravlja, oblikuje, razmnožuje pisno gradi- vo, da s kasetofonom in videorekorderjem sam posname in pripravi posnetke, potrebne za poučevanje. Prav to daje mentorjem možnost, da po potrebi sami prilagajajo program glede na potrebe in želje posameznika ali skupine, čeprav je pomembna podpora poučevanju učbenik.

$\mathrm{S}$ tem se je začel način dela $\mathrm{z}$ odraslimi spreminjati tudi na področju jezikovnega izobraževanja. Jezikovno poučevanje $v$ šoli še vedno poteka po programih, ki jih določi ministrstvo, in tudi koněna evalvacija je izpeljana po enotnih merilih za celotno generacijo ali populacijo mladih, področje jezikovnega izobraževanja odraslih pa je dobilo neslutene razsežnosti, ki ponazarjajo raznolikost potreb in interesov sodobnega človeka ( $v$ poslovnem svetu, turizmu, pravu, medicini, mednarodnih odnosih, zasebnem življenju itd.).

Odločen odmik od osredotočenosti na metode pomenijo sedemdeseta leta, ko se je začela v razvitem svetu uveljavljati informacijska družba in ko so paradigme proizvodne družbe zamenjale nove paradigme: pomembno ni več proizvajati, ampak komunicirati. V jezikovnem izobraževanju so v zvezi s tem pomembni avtorji, kot so Widdowson (1978), Wilkins (1976), van Ek (1975), Trim (1973), Richterich (1977) in drugi, ki so se začeli poglobljeno spraševati o tem, kaj naj bi ljudje dejansko znali povedati, razumeti, brati in pisati oziroma kakšno funkcijo ima razvijanje teh štirih spretnosti. »Poznati jezik ne pomeni le razumeti, govoriti, brati in pisati stavke. Pomeni tudi vedeti, kako se ti stavki uporabljajo pri komunikaciji.« (Widdowson, 1978, str. 11) Poudarili so vprašanje pomena, ki ga ima znanje tujega jezika za potrebe komunikacije. To pa je povezano s celovitim upoštevanjem in obravnavanjem okoliščin, s katerimi je učenje tujega jezika v tesni zvezi: kdo so dejansko slušatelji, kakšne so njihove potrebe, kakšno znanje potrebujejo, zakaj ter kje bodo pridobljeno znanje potrebovali in uporabljali. Wilkinsov funkcijsko-pojmovni pristop se osredotoča na jezik za komunikacijske potrebe študentov. Zajema socialno vedenje in gramatikalno kompetentnost na določeni stopnji ter primernost jezika za odnose med govorcema, na primer v okoliščinah »tujec s tujcem« (van Ek, 1975). 


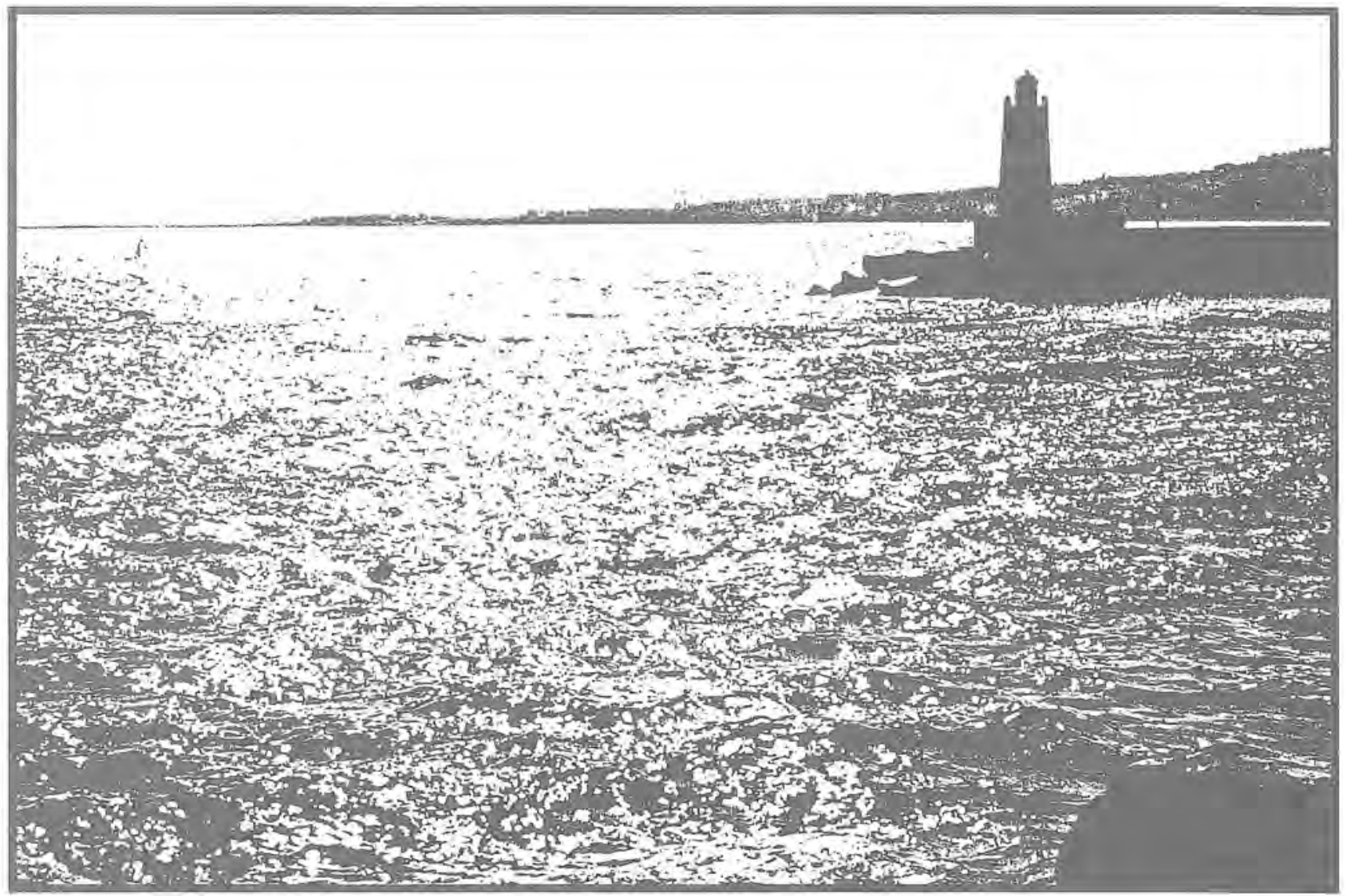

V okviru Sveta Evrope (Trim in drugi, 1973) je tako nastala vrsta študij in raziskav, ki so omogočile celovit vpogled $\mathrm{v}$ razsežnosti jezikovnega poučevanja. Med prvimi in najbolj znanimi je »Threshold Level« (fr. Niveau-seuil, it. Livello soglia, slov. raven osnovnega praga), ki je opredelila področja jezikovnega znanja in raven splošne komunikativne kompetence za uporabo tujega jezika. Različne ravni obvladovanja jezikovnih spretnosti so bile kasneje podrobneje opredeljene $\mathrm{v}$ dokumentu Skupni evropski okvir smernic za učenje in poučevanje tujih jezikov (Svet Evrope, 1997), ki razvršča jezikovne sposobnosti na šest ravni. Pomembno je, da je bil projekt namenjen predvsem odraslim. To je avtorje projekta že na začetku postavilo pred jasna izhodišča: ciljev izobraževanja ne more postavljati mentor ali izvajalec le na podlagi lastnih predvidevanj, ampak morajo nastati kot rezultat dejansko ugotovljenih potreb, želja in zmožnosti tistih, ki se jezika učijo.

$\mathrm{Za}$ izhodišče za oblikovanje jezikovnih programov Coste tako postavlja vprašanja (Cortes, 1998):

- kdo je slušatelj oziroma kakšen status, kakšno vlogo in kakšne posebnosti bo imel kot uporabnik tujega jezika;

- kdo bodo njegovi sogovorniki (status, vloga in posebnosti) pri sporazumevanju v tujem jeziku;

- kakšna govorna dejanja bo moral biti sposoben realizirati kot odgovor na takšna govorna dejanja;

- v katerih okoliščinah bo moral realizirati ta govorna dejanja; 
- v povezavi s katerimi izkušenjskimi področji bo potekalo jezikovno sporazumevanje in na kakšne pojme se bo nanašalo.

Tak način pojmovanja postavlja jasno razmejitev do konceptualiziranja poučevanja na podlagi učne metode, obenem pa tudi jasen odmik od principov, ki veljajo za šolsko okolje. Izobraževanje odraslih kot fenotipsko izobraževanje mora izhajati iz potreb v okolju in potreb posameznikov, ki se izobražujejo, zato mora tudi jezikovno izobraževanje izhajati iz dejanskih okoliščin in potreb posameznikov, ki se učijo. Prvi korak k temu je ugotavljanje potreb in okoliščin, ki so povezane $\mathrm{z}$ učenjem in uporabo tujega jezika.

\section{UGOTAVLJANJE JEZIKOVNIH POTREB Z VIDIKA PROGRAMIRANIA}

Ugotavljanje potreb in interesov je izhodišče za določanje ciljev, ki jih želimo doseči z jezikovnim izobraževanjem. Pri tem pojem ugotavljanja potreb ne zadeva zgolj potreb, interesov in želja, ki jih imajo posamezniki ali skupine odraslih glede pričakovanega jezikovnega znanja in sposobnosti. Gre za osvetlitev vrste dejavnikov in okoliščin, $\mathrm{ki}$ jih je treba upoštevati pri oblikovanju in izvedbi jezikovnega programa.

V strokovni literaturi se je zanimanje za vprašanje ugotavljanja potreb izrazito povečalo $\mathrm{v}$ sedemdesetih letih, ko se je v izobraževanju odraslih povečala individualizacija in so se začeli odnosi naglo demokratizirati. Takrat je nastalo nekaj kompleksnih raziskav o načinih in postopkih za ugotavljanja jezikovnih potreb (na primer Munby, Richterich). Te raziskave so dejansko izraz zavesti, da se ciljne skupine $\mathrm{v}$ jezikovnem izobraževanju vse bolj diverzificirajo, saj so potrebe po znanju tujih jezikov izraz čedalje bolj kompleksne in dinamične realnosti. Programe, ki bi bili čimbolj prilagojeni posebnostim različnih ciljnih sku- pin, je mogoče pripraviti le na podlagi čim boljšega poznavanja njihovih posebnosti in potreb. Zato je tudi razumljivo, da je večina teh raziskav nastala na področju učenja/poučevanja tujih jezikov za posebne namene (poslovni jezik, pravni jezik ipd.), torej na področju, kjer se slušatelji svojih potreb veliko jasneje zavedajo in zato tudi laže postavljajo svoje pogoje ter vplivajo na potek izobraževanja.

Pri ugotavljanju potreb gre za zbiranje podatkov o tem, kdo so slušatelji, čemu se učijo tujega jezika, kakšno predstavo imajo glede uporabe pridobljenega znanja tujega jezika ipd. Richterich (1985) pri tem poudarja, da zbiranje teh podatkov zadeva slušatelja, mentorja, izobraževalno ustanovo, podjetje (ali organizacijo), v okviru katere se bo znanje tujega jezika uporabljalo, in tudi širšo skupnost. Razlogi za učenje tujega jezika in predstava o uporabi jezikovnega znanja sicer izhajajo iz vsakega posameznika, vendar učenje in dejanska uporaba jezikovnega znanja potekata $v$ interakciji z drugimi akterji, saj se slušatelj nikoli ne uči v popolni izolaciji, predvsem pa se pridobljeno znanje preveri in potrdi šele $\mathrm{v}$ stiku $\mathrm{z}$ drugimi ljudmi, $\mathrm{v}$ konkretnih okoliščinah.

Med pojmi, ki jih najpogosteje srečamo v strokovni literaturi, so pojmi jezikovne potrebe, ciljne potrebe in učne potrebe. Richterich meni, da jezikovne potrebe odraslih, ki se učijo živega jezika, ustrezajo zahtevam, ki nastanejo pri uporabi jezika $v$ različnih okoliščinah družbenega življenja posameznikov ali skupin (Richterich, 1973, str. 36). Galisson in Coste (1976, str. 504) opredeljujeta jezikovne potrebe $\mathrm{z}$ vidika pogojev, potrebnih za izražanje $v$ določenem tujem jeziku. Gre za predvidenje in opis dejanskega jezika, ki ga bodo posamezniki ali določene skupine posameznikov uporabljali, ko se bodo jezika naučili, in za analizo tega, kaj posameznik potrebuje, da bo sposoben komunicirati v določenem jeziku $\mathrm{v}$ situacijah, ki niso učne situacije in niso odvisne od njega.

Hutchinson in Waters (1987) opozarjata na to, da samo poznavanje ciljnih situacij ni do-
AS 2/20n 
volj za oblikovanje jezikovnega programa, zato razlikujeta med ciljnimi potrebami (target needs) in učnimi potrebami (learning needs). Ciljne potrebe opredeljujeta kot vse. kar bo moral biti slušatelj sposoben narediti $v$ ciljni situaciji, učne potrebe pa kot vse, kar bo moral slušatelj narediti, da se bo tega naučil (predvsem, kje se bo učenje glede na predznanje začelo). Analiza ciljne situacije zadeva uporabo jezika, vendar je to le en segment, saj je treba nekaj vedeti tudi o učenju jezika.

Programiranje
mujno zahteva od-
govor na vpraša-
nje: čemu se bomo
ukvarjali z določe-
no temo.
"Analiza ciljne situacije nam lahko pove, kaj ljudje počnejo z jezikom. Vedeti pa moramo tudi to, kako se ljudje naučijo tega, kar počnejo $\mathrm{z}$ jezikom. « (Hutchinson in Waters, 1987, str. 63)

Namen ugotavljanja potreb je predvsem določiti cilje jezikovnega izobraževanja, obenem pa je mehanizem, s katerim se posamezne skupine udeležencev jasneje zavejo svoje vloge in položaja: mentor pri razvijanju posluha za nove andragoške in didaktične probleme, avtorji učbenikov pri razumevanju in interpretiranju kompleksnosti možnosti izobraževanja, izobraževalne ustanove pri načrtovanju novih programov in oblik jezikovnega izobraževanja.

\section{OPREDELITEV CILJEV JEZIKOVNEGA IZOBRAŽEVANIA}

Namen ugotavljanja potreb je zbrati čim več takih informacij o udeležencih, na podlagi katerih bi bilo mogoče čimbolj smiselno in smotrno opredeliti cilje izobraževanja.

Pri tujih jezikih pogosto prihaja do nejasnosti, ko mentorji ali izvajalci opredeljujejo cilje, smotre in vsebine programa (Marentič - Požarnik, 1979, str. 85). Velikokrat se zgodi, da opredelijo le vsebine, snov, ki jo bodo obravnavali, premalo definirano pa ostane vpraša- nje, čemu se bodo ukvarjali z določeno snovjo, na primer temo ali slovničnimi strukturami, in kaj naj bi bil slušatelj na koncu sposoben narediti, povedati, izraziti. Če je učna enota posvečena na primer zaposlovanju v Italiji, se mora mentor sicer res vprašati, katere teme in situacije bodo to problematiko ponazorile, vendar je bistveno to, kaj naj bi bil slušatelj ob koncu tega poglavja sposoben narediti: ali bo zmožen pravilno razumeti oglase za službo in napisati prošnjo za službo; napisati kratek sestavek, v katerem bi primerjal različne kategorije poklicev; argumentirano predstaviti svoj pogled na vpliv globalizacije na zaposlovanje v razvitem svetu; napisati svoj življenjepis; pripraviti se na razgovor za službo? Teme in situacije so le splošen okvir, v katerem je mogoče razvijati in dosegati zelo različne cilje. Ce cilji niso natančno določeni, poučevanje plava $\mathrm{v}$ zraku in ostane nedefinirano.

Teme jezikovnega programa so lahko začrtane za dokaj široko ciljno skupino: na primer za pravnike $v$ državnih organih, ki sodelujejo z Brusljem na področju kmetijstva, $v$ okviru te skupine pa je lahko več podskupin glede na potrebe, ki jih imajo, in cilje, ki jih želijo doseči: nekateri se bodo morali sporazumevati predvsem po telefonu, drugi bodo za krajša obdobja odhajali v Bruselj, kjer se bodo pogajali z bruseljskimi kolegi, tretji bodo študirali zakonodajo držav članic EU in pripravljali predloge zakonov, četrti bodo s kolegi v Bruslju komunicirali predvsem pisno. Pravzaprav se bodo lahko vsi izobraževali po enakem programu oziroma konceptu vsebin (teme: institucije EU, principi pogajanj, primerjava kmetijskih zakonodaj posameznih članic EU, pravni jezik, osnove poslovne korespondence ipd.). Vendar končnega, operativnega cilja ne bodo smeli spustiti izpred oči: izobraževanje se bo dejansko končalo šele, ko se bodo znali prvi suvereno in učinkovito pogovarjati po telefonu, drugi pogajati na srečanjih, tretji razumeti pravne dokumente in četrti pisati dopise ter podobne dokumente. 
Druga nevarnost pri posebnih ciljnih skupinah pa je pretirana naravnanost na cilje izobraževanja. Hutchinson in Waters opozarjata, da je na področju angleščine za posebne namene prav pristop, osredotočen na slušatelja (learner-centred approach), praviloma zelo zavajajoč, saj gre pri ugotavljanju potreb za to, da se ugotovi, kaj bi slušatelj rad obvladal, vendar se nato ves program skrči in osredotoča le na to, da je slušatelj to sposoben narediti, pri tem pa se bogastvo jezika navadno pretirano osiromaši in zoži le na tisti segment jezika in kulture, ki je $\mathrm{v}$ neposredni povezavi z danimi spretnostmi ali sposobnostmi.

Pomembno je, da programer mentor najde pravo razmerje med splošnim in posameznim. Potrebe posameznika ali skupine so vsekakor vodilo pri oblikovanju programa in njegovi izvedbi, saj se izobraževanje lahko konča šele, ko so te potrebe resnično izpolnjene. Obenem pa je dejstvo, da se ustreznost in pravilnost aplikacije jezikovnega znanja povečujeta s širino in poglobljenostjo drugih, komplementarnih vrst znanja (s področja kulture, civilizacije, psihologije, zgodovine, sociologije, ekonomije ipd.), ki posameznika pripravljajo na to, da je njegovo jezikovno znanje $\gg$ transferno $\ll$, se pravi uporabno $v$ razIičnih življenjskih in poklienih okoliščinah.

Prav $v$ tem je tudi vzgojna komponenta jezikovnega izobraževanja. S pridobivanjem znanja tujega jezika se spreminja posameznikov odnos do sveta, do drugih kultur. Bolj poglobljeno je znanje, manj je neznank, manjšsi so lahko tudi strahovi in zavore pri sprejemanju drugačnosti, ki jo za vsakogar pomeni stik s tujci. Prav zato je pomembno, da programiranje najde pravo ravnovesje med preveliko osredotočenostjo na cilje $v$ strogo operativnem smislu (učnociljna strategija) in ukvarjanjem z vsebinami v splošnem, širšem smișlu (učnosnovna strategija).

Jasno oblikovani cilji imajo še eno temeljno funkcijo: so namreč izhodišče za evalvacijo.
Cilji izobraževalnega programa so pri odraslih dejansko doseženi šele, ko je posameznik sposoben uporabiti pridobljeno znanje oziroma $v$ konkretnih okoliščinah dokazati, da ga je sposoben uporabiti. Da pa bo sebi in drugim to lahko dokazal, je treba »opredeliti okoliščine, pod katerimi bo slušatelj pokazal, ali je smoter dosegel (...), in končno opisati kriterij, ki ga bomo lahko

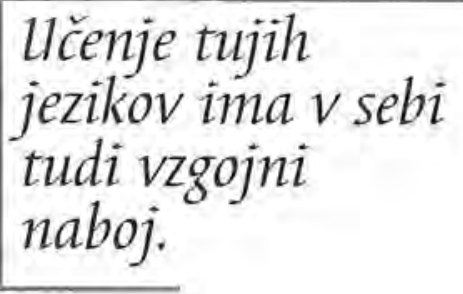
uporabili, da bomo učenčevo storitev še označili kot zadovoljivo« (Marentič - Požarnik, 1978, str. 40). Določanje ciljev je tako tesno povezano $\mathrm{z}$ načinom in merili za evalvacijo.

\section{PROGRAMIRANIE V JEZIKOVNEM IZOBRAŽEVANJU}

Programiranje je tista stopnja pri oblikovanju jezikovnega programa, na kateri se na podlagi potreb določene ciljne skupine naredi vsebinski koncept. To je proces, $\mathrm{v}$ katerem se grobi podatki o potrebah interpretirajo tako, da nastane zaokrožena celota učnih vsebin in epizod, katerih končni cilj je pripeljati slušatelja do določene stopnje znanja. Gre za uporabo razpoložljivih teoretičnih in praktičnih informacij, na podlagi katerih nastane vsebinski koncept programa. Zanj se nato $v$ fazi planiranja izberejo viri, prilagodi in napiše gradivo, predvidijo in razvijejo primerne metode dela ter določijo postopki evalvacije, s katerimi se ugotavlja napredovanje proti zastavljenim ciljem in njihovo doseganje (Hutchinson in Waters, 1987).

Modelov, s katerimi naj bi se jezikovni cilji preoblikovali $\mathrm{v}$ jezikovne vsebine, je veliko. Med avtorji so najpogosteje omenjeni Valette in Disick (1972), Bung (1973), Dalgalian (1981), najširši odmev in vpliv pa ima nedvomno model Raven osnovnega praga - $\gg$ Threshold Level (van Ek, 1975) in njegove različice za posamezne evropske jezike.
AS 2/201 
Model Raven osnovnega praga razdeli vsebinske sklope jezikovnih programov na:

- komunikacijske funkcije (vse tisto, kar skušamo doseči z jezikom kot govorci ali pisci): seznam komunikacijskih funkcij in govornih/pisnih spretnosti, ki jih mora slušatelj obvladati na določeni stopnji, na primer pri medsebojnih stikih (navezovanje stikov, predstavljanje sebe in drugih ipd.), pri pridobivanju in prenašanju informacij, izražanju čustev, mnenj ipd.;

- teme: seznam tem/tematskih področij (na primer vsakdanje življenje, bivalno okolje, hrana in pijača, prosti čas, zgodovina, mediji ipd.), ki so okvir za učenčevo izražanje v tujem jeziku;

- situacije: seznam ima enak namen kot seznam tematskih sklopov; primeri: nakupovanje, pisanje pisma prijatelju, telefoniranje poslovnemu partnerju ipd.;

- besedila: katalog različnih zvrsti besedil za razvijanje slušnega in bralnega razumevanja (na primer radijska in televizijska obvestila, vozni redi vlakov, dopisi) ter pisnega izražanja (na primer obrazci, prijavnice, zasebna in polformalna pisma, čestitke, pritožbe), ki bi jih moral biti slušatelj sposoben razumeti in/ali izdelati na določeni stopnji;

- slovnične strukture: seznam določa vrsto in obseg slovničnih struktur, ki bi jih moral slušatelj obvladati na določeni stopnji učenja.
$\mathrm{V}$ zadnjih dvajsetih letih so raziskave na področju jezikovnega izobraževanja opozorile, da je jezik sistem, vpet v druge sisteme, ki so širši kot jezik sam, zato je za poglobljeno razumevanje jezikovnega delovanja $v$ vsej njegovi zapletenosti potrebno široko interdisciplinarno znanje (Grosman, 1994) s področja jezikoslovja, filozofije, antropologije, sociologije in psihologije (Stern, 1992), Richterich (1985) poudarja, da na samo programiranje vplivajo zlasti jezikoslovje (morfologija, sintaksa, semantika, besedni zaklad, funkcije, fraze ipd.), psihologija (intelektualne dejavnosti, proces učenja in osvajanja, kognitivno in afektivno, sposobnosti, vedenje ipd.) in sociologija (situacije, medsebojni odnosi, kulturne razlike, hierarhija odnosov, stališča, obnašanje, običaji ipd). Da se v tujem jeziku pravilno in primerno sporazumevamo, moramo poznati določeno število besed, besednih zvez, stavčnih struktur, sposobni moramo biti pravilno razumeti sogovornike in znati odreagirati, za to pa moramo imeti tudi določeno znanje o tem, kakšne so kulturne posebnosti različnih okolij, v katerih bomo jezik uporabljali. V zadnjem desetletju so zato v ospredju raziskave medkulturnih razsežnosti na vseh ravneh jezikovnega izobraževanja (Hymes, 1987; Kramsch, 1993; Grosman, 1993; Štrukelj, 1994) in s tem povezana sposobnost vživljanja $v$ druge, prepoznavanja pomembnih značilnosti okolja in sposobnost dekodiranja socialnih sporočil.

\section{PRISTOP K PROGRAMIRANJU JEZIKOVNIH PROGRAMOV}

Prvi koncept vsebin nastane tako, kot si ga izobraževalec programer lahko zamisli na podlagi okvirnih informacij o ciljni skupini, zakonitosti stroke in lastnih izkušenj. Pri jezikovnih programih gre predvsem za to, katera govorna dejanja, jezikovne spretnosti in znanje so potrebni za pridobitev jezikovnih kompetenc, ki jih želimo razviti kot cilj izobraževanja. Pri tem gre za povezano celoto komunikacijskih funkcij, slovničnih struktur, tem in situacij ter različnih zvrsti besedil. Druga faza programiranja pa pomeni konkretizacijo programa glede na konkretne okoliščine in profil udeležencev, pri čemer gre predvsem za opredelitev ravni obvladovanja štirih jezikovnih spretnosti (slušnega in pisnega razumevanja ter ustnega in pisnega izražanja) oziroma konkretnih okoliščin, v katerih bo izobraževanje potekalo, od jezikovnega predznanja udeležencev, izobrazbe, do časovnega okvira, v katerem mora biti izobraževanje končano.

Vzemimo za primer natakarje v slovenskem obmorskem hotelu, ki se morajo naučiti nemščine, ker bo v prihodnji turistični sezoni pre- 


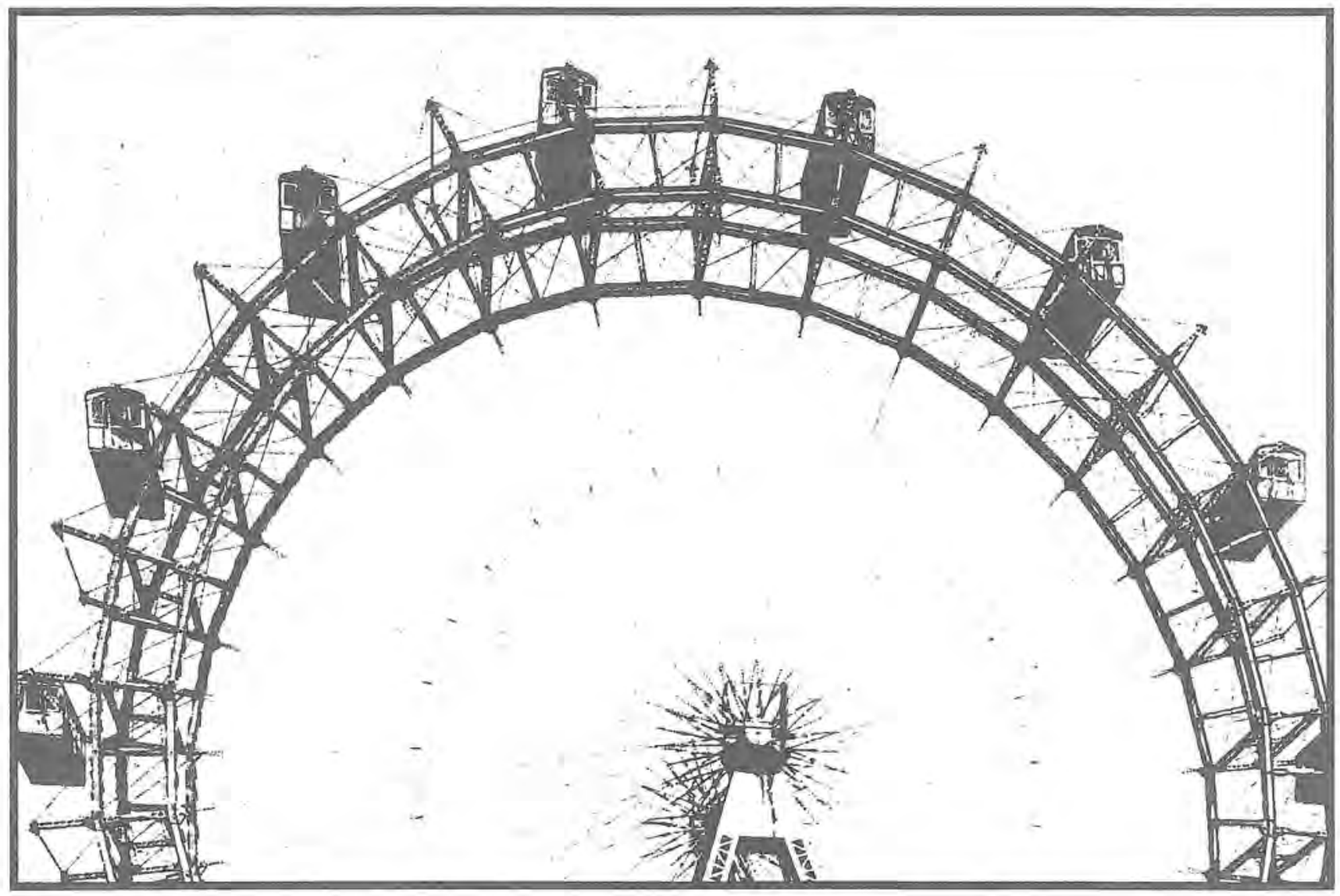

težen del gostov iz Nemčije in Avstrije. Prvo predstavo o konceptu programa si bo izobraževalec programer ustvaril že na podlagi lastnih izkušenj in znanja. Ker gre za natakarje, bodo teme in situacije zadevale predvsem delovno okolje, $\mathrm{v}$ katerem bodo potrebovali znanje nemščine: prihod gostov $\mathrm{v}$ restavracijo, namestitev pri mizi, izbira jedi in pijače, naročanje, plačilo ipd. $V$ okviru teh tem in situacij pa bo moral izobraževalec programer opredeliti tudi govorna dejanja in jezikovne spretnosti, ki jih mora natakar osvojiti/obvladati, da se bo $v$ teh situacijah uspešno sporazumeval $\mathrm{z}$ gosti: pozdraviti, ponuditi prostor pri mizi, pojasniti vsebino jedilnika, ponuditi pijačo, se posloviti od gostov ipd. Na podlagi lastnih izkušenj in zakonitosti stroke si bo izobraževalec okvirno predstavljal tudi to, kakšna raven poznavanja ter obvladovanja slovničnih struktur in besednega zaklada bo za to potrebna.

To je prvi osnutek programa, ki ga izobraževalec lahko naredi na podlagi splošnih zakonitosti oblikovanja jezikovnih programov. $\mathrm{Ne}$ glede na predznanje in specifične potrebe slušateljèv je dejstvo, da bo moral slušatelj za osvojitev teh jezikovnih spretnosti razviti sposobnost slušnega razumevanja in ustnega izražanja (da bo goste razumel in se $\mathrm{z}$ njimi pogovarjal), prav tako pa tudi sposobnost pisnega razumevanja, branja in pisanja $v$ teh okoliščinah (da bo na primer razumel in prebral jedilni list). Raven sposobnosti razumevanja in izražanja je določena glede na zastavljene cilje. Obenem s konkretnimi okoliščinami in govornimi dejanji ter jezikovnimi spretnostmi, ki se pri tem pojavljajo, bo izo- 
braževalec programer moral predvideti tudi sirši tematski okvir, v katerega bo vpeto učenje jezika, predvsem kar zadeva spoznavanje kulturnih, družbenih in socialnih vidikov, ki so povezani s sporazumevanjem z nemškimi gosti (kultura gostov in kultura okolja; bonton, navade pri mizi, gastronomija, kulturne znamenitosti kraja, dežele in podobno). Prvi koncept programa tako že odseva principe posamičnega (ozko jezikovnega) in splošnega (kultura, v katero je jezik kot sredstvo komunikacije vpet). Ne glede na posebne želje skupine ali posameznikov se ta osnovni koncept ne spreminja.

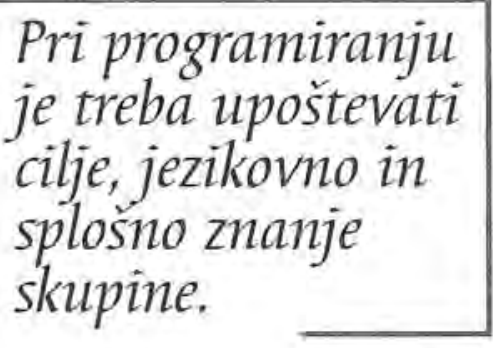

$\mathrm{V}$ naslednji fazi programiranja pa bo izobraževalec programer ta koncept prilagodil konkretnim okoliščinam oziroma podatkom o udeležencih: jezikovno predznanje slušateljev, njihovo starost in izobrazba, čas, ki je na voljo za izvedbo izobraževanja, ipd. Pri tem se bo verjetno izkazalo, da večina natakarjev nima predznanja nemščine, le nekaj bo takih, ki so se nemščino že učili in so jo morda tudi uporabljali v svojem poklicu, zato jih ne bo mogoče obravnavati kot popolne začetnike. Glede na različno jezikovno predznanje slušateljev se bo osnovni koncept programa prilagodil predvsem v segmentu zahtevnosti govornih dejanj in ravni jezikovnih struktur, ki jih sestavljajo. Program začetne skupine bo osredotočen na spoznavanje in obvladovanje osnovnih govornih dejanj, na nadaljevalni stopnji pa bodo ta govorna dejanja nadgrajena in razširjena. Na začetni stopnji bo obravnavanje morfoloških in sintaktičnih struktur imelo funkcijo oblikovanja osnovnega orodja za pravilno razumevanje in izražanje, na nadaljevalni stopnji pa bo šlo predvsem za njihovo utrjevanje in poglabljanje. Pri tem se osnovni koncept programa ne bo spremenil, pino. Vendar bo to $v$ nadaljevanju vplivalo na

načrtovanje oziroma na priprayo konkretnega izvedbenega načrta, ko bo treba pripraviti gradivo, napisati oziroma izbrati dialoge, pripraviti vaje za utrjevanje razumevanja, slovnične vaje ipd. Tudi intenzivnost dela in skoncentriranost učnih epizod bo lahko bistveno drugačna za začetnike kot za slušatelje, ki že imajo predznanje.

Seveda pri posamezni ciljni skupini razlike $v$ skupini niso vedno »jezikovne narave in niso omejene le na jezikovno predznanje. Pri skupini natakarjev, ki smo jih vzeli za primer, bi šlo lahko za popolne začetnike, ki pa bi se med seboj bistveno razlikovali recimo po službeni hierarhiji (navadni natakarji, vodje strežbe), izobrazbi ali starosti. Morda bi del skupine dobro obvladal angleščino, del skupine pa nobenega tujega jezika. Zato bi se lahko že $\mathrm{z}$ njihove strani pojavila želja ali zahteva, da se te razlike upoštevajo.

V prvi fazi programiranja gre predvsem za to, da se koncept vsebin naredi na podlagi skupnih značilnosti ciljne skupine. Bodisi da gre za natakarje $v$ hotelu, za telefoniste $v$ državni administraciji, za upokojence, ki potujejo $\mathrm{z}$ umetnostnozgodovinskim krožkom bodisi za inženirje $v$ gradbenem podjetju, bo prvi koncept vsebin oblikovan glede na jezikovne cilje, ki jih želi doseči skupina. V drugi fazi programiranja pa bo programer pozoren na razlike $\mathrm{v}$ skupini. Zanimalo ga bo predvsem to, ali razlike v skupini dejansko vplivajo na koncept vsebin oziroma komponente jezikovnega programa, ki ga je zastavil. Če gre za razlike v jezikovnem predznanju, bo vsekakor moral $v$ okviru zastavljenega programa predvideti različne pristope $\mathrm{k}$ razvijanju jezikovnih spretnosti, govornih dejanj in slovnice za popolne začetnike in za tiste, ki že imajo nekaj znanja. Če gre za velike razlike $v$ hierarhiji (na primer med natakarji) ali za velike razlike $\mathrm{v}$ izobrazbi (na primer med upokojenci), bo temu verjetno prilagodil predvsem tisti del programa, ki zadeva kulturo in civilizacijo, deloma pa tudi je- 
Ker učenje tujih jezikov praviloma predpostavlja sistematično in postopno razvijanje razumevanja in izražanja, za kar je potrebno obvladovanje fonetike, morfologije, sintakse in tudi poznavanje širšega kulturnega in civilizacijskega okvira, je programiranje zelo kompleksno in zahtevno.

zikovni del. Če so razlike po hierarhiji ali izobrazbi prevelike, gre pravzaprav za dve različni ciljni skupini. V tem primeru mora za vsako skupino pripraviti poseben program.

Nekaterih razlik v skupini izobraževalcu programerju $\mathrm{v}$ fazi programiranja morda ne bo treba upoštevati, bodo pa izhodišče za fazo planiranja. Starostna razlika praviloma ni dejavnik, ki bi narekoval razlike in prilagajanje v konceptu vsebin, lahko pa je pomembna pri planiranju izvedbe, predvsem pri izbiri metod dela. Tudi znanje drugih tujih jezikov za vsebinski koncept programa navadno ni ključno, pri planiranju izvedbe in med potekom izobraževanja pa ga je mogoče upoštevati.

Pisno razumevanje in izražanje je mogoče razvijati le z učnim gradivom, za sistematično razvijanje slušnega razumevanja pa so potrebni avdioposnetki. Takega gradiva ni mogoče pripraviti v kratkem času, zato je treba v jezikovnem izobraževanju že $v$ fazi programiranja razmisliti tudi o tem, kakšno gradivo (učbenik, skripta, multimedijski paket) bo podlaga za izobraževanje. V jezikovnem izobraževanju žal sam koncept vsebin, ki ga izobraževalec naredi v prvi fazi programiranja, ne pomeni veliko, če ni možnosti, da bi se pripravilo ali priredilo ustrezno gradivo.

Bolj ko je ciljna skupina specifična, večja je verjetnost, da ni primernega gradiva, po katerem bi se skupina ali posameznik lahko učila. Če gre za skupino poslovnežev, ki bi ràdi izpopolnili svoje znanje angleščine za potrebe komunikacije s tujimi partnerji, je zelo verjetno, da bo med razpoložljivimi učbeniki in gradivom mogoče najti vsaj enega, ki bo lahko po- dlaga za poučevanje. Če pa gre za telefoniste v državni upravi, ki se morajo naučiti francoščine, da bodo lahko odgovarjali na telefonske klice francosko govorečih uradnikov iz Evropske unije, je zelo verjetno, da ne bo posebnega gradiva za to ciljno skupino, zato bo moral najverjetneje izobraževalec sam sestaviti gradivo, s katerim si bo pomagal pri izobraževanju.

\section{VLOGA ŠTUDIJSKEGA GRADIVA PRI PROGRAMIRANJU (IZOBRAŽEVALNI PROGRAM - UČ̉BNIK)}

V jezikovnem izobraževanju je študijsko gradivo podlaga jezikovnega poučevanja, zato ga avtorji običajno obravnavajo $\mathrm{v}$ tesni povezavi $\mathrm{s}$ samim programom ali ga celo $\mathrm{z}$ njim enačijo. To je razumljivo iz več razlogov. Prvič, kot sem že poudarila, si jezikovnega izobraževanja brez študijskega gradiva na začetnih stopnjah ne moremo predstavljati. Drugič, avtorji teoretskih razprav govorijo o jezikovnih programih na splošni, abstraktni ravni, kjer model poučevanja predpostavlja, da mentor na podlagi ugotovljenih potreb in zastavljenih ciljev sam napiše študijsko gradivo. V praksi pa mentorji navadno nimajo možnosti, da bi na podlagi lastnega koncepta programa tudi dejansko napisali študijsko gradivo. Avtorji modelov tega navadno ne upoštevajo, zato je razumljivo, da $v$ praksi njihovi modeli nișo uporabni, če mentor nima primernega znanja, da bi lahko ugotovljene potrebe in svoj koncept vsebin primerno uskladil s študijskim gradivom, ki ga ima na voljo.

V praksi jezikovnega izobraževanja se praviloma srečamo s temi možnostmi:

\section{1. Študijsko gradivo obstaja in je lahko primerna podlaga za izvedbo programa}

$\mathrm{V}$ tem primeru mora izobraževalec $\mathrm{v}$ fazi programiranja ugotoviti, kakšne so razlike med vsebinskim konceptom programa in 
vsebinskim konceptom študijskega gradiva, Vsebinski koncept programa je glavni, referenčni okvir, saj so $v$ njem opredeljeni cilji, ki jih mora določena ciljna skupina doseči, študijsko gradivo pa je ( $v$ kombinaciji z drugimi viri) predvsem sredstvo za doseganje teh ciljev.

Ciljev programa, bodisi pri programiranju bodisi pri izvedbi, ne smemo podrediti vsebinam študijskega gradiva, predvsem kadar se vsebine studijskega gradiva skoraj popolnoma pokrivajo $\mathrm{z}$ vsebinami programa. Cilji študijskega gradiva so navadno zastavljeni splošno in širše od ciljev, ki jih želi doseči posamezna skupina, zato morata imeti progra-

Potrebe po posebnih učnih gradivih naraščajo. mer in/ali mentor glavne cilje, do katerih morata pripeljati skupino, stalno pred očmi. Študijsko gradivo mora imeti vedno funkcijo pripomočka, sredstva, s katerim se uresničujejo cilji programa.

Če se študijsko gradivo in program ujemata le delno, bo izobraževalec $\mathrm{v}$ fazi programiranja predvidel, katera poglavja študijskega gradiva so primerna, katere naloge in vaje pridejo $v$ poštev in v kakšnem zaporedju, da bo program $\mathrm{v}$ fazi izvedbe deloval koherentno in zaokroženo.

\section{2. Študijsko gradivo ne obstaja}

$\mathrm{V}$ tem primeru bo moral izobraževalec sam pripraviti gradivo. Gre predvsem za posebne ciljne skupine, ki se ne pojavljajo pogosto in imajo ozko profilirane potrebe glede jezikovnega znanja (na primer telefonisti $\mathrm{v}$ drŽavni upravi, sprevodniki na mednarodnih vlakih, inženirji na gradbišču v tujini). Če za potrebe take ciljne skupine ni mogoče uporabiti enega samega študijskega gradiva, bo izobraževalec sestavil gradivo iz različnih razpoložljivih virov: učbenikov, zbirk vaj, časopisnih člankov, avđio- in videoposnetkov, večino nalog in vaj pa bo verjetno sestavil med samim potekom izobraževanja glede na odzive in potrebe slušateljev. Kadar gre za zelo specifične ciljne skupine, se faze prilagajanja programa in načrtovanja (izbira virov in metod dela) prepletejo $\mathrm{v}$ fazi izvedbe. Mentor pravzaprav programira in načrtuje sproti med samim potekom izobraževanja. Tak način programiranja seveda zahteva od mentorja veliko znanja, spretnosti, sposobnosti predvidevanja in vživljanja v slušatelje. V jezikovnem izobraževanju je očitna težnja usmerjanja $\mathrm{k}$ manjšim skupinam in posameznikom z ozko specializiranimi jezikovnimi potrebami, za katere je treba programirati tako rekoč sproti. To mentorju sodobna tehnologija tudi omogoča: študijsko gradivo je mogoče pripraviti sproti, glede na potrebe in interese, ki se pojavijo med samim potekom izobraževanja.

\section{3. Študijsko gradivo obstaja, vendar zaradi načina izvajanja ne more biti primerna podlaga za učenje}

Do take situacije lahko pride, kadar želimo program izvajati v obliki, ki ima posebne zakonitosti. Tako je na primer izobraževanje na daljavo, pri katerem študijsko gradivo prevzame vlogo mentorja pri posredovanju vsebin. $\mathrm{V}$ tem primeru je vsebinski koncept programa obenem tudi vsebinski koncept študijskega gradiva, saj študijsko gradivo prevzame vlogo mentorja in mora pripeljati študenta do zastavljenih ciljev.

Za potrebe take oblike izobraževanja mora izobraževalec pripraviti posebno gradivo $\mathrm{v}$ skladu z zakonitostmi, ki jih je treba upoštevati pri programiranju študijskega gradiva za samostojni študij. Lahko bo dopolnil razpoložljivo študijsko gradivo in dodal tiste dele, ki nadomestijo mentorja (navodila, razlago, komentarje ipd.), ali pa pripravil povsem novo gradivo.

Vloga študijskega gradiva v razmerju do pro- 
grama se na področju jezikovnega izobraževanja spreminja in odsevà značilnosti spreminjanja paradigem v vzgoji in izobraževanju. Bolj ko potrebe postajajo individualne, bolj dinamično in nestereotipno je programiranje. Glede na raznovrstnost okoliščin, $v$ katerih odrasli potrebujejo znanje tujih jezikov, se potreba po programiranju vsebin pojavi skoraj pri vsaki novi skupini ali posamezniku, s tem pa tudi potreba po primernem študijskem gradivu, ki ga je vse pogosteje treba sproti sestaviti ali prirediti iz različnih virov, ki so na voljo. Pri tem pa je še toliko pomembnejše, da je osnovna struktura programa jasno začrtana in da izobraževalec pri selekciji virov teh ciljev ne izgubi izpred oči.

\section{JEZIKOVNO PROGRAMIRANJE V RAZMERJU DO PLANIRANJA}

Andragogika opredeljuje fazo planiranja kot tisto fazo pri pripravi izobraževalnega programa, v kateri se na podlagi koncepta vsebin naredi izvedbeni načrt, ki je podlaga za praktično izvedbo izobraževanja. Če gre pri programiranju predvsem za »vsebino«, se planiranje ukvarja $\mathrm{s} »$ formo , torej z vprašanjem, v kakšni obliki in kako se bo slušatelj učil tujega jezika. V fazi planiranja se glede na čas, ki je na voljo za izvedbo izobraževanja, predvidi intenzivnost dela in naredi razpored učnih epizod, določijo se primerne oblike in metode dela ter izberejo viri znanja, ki so podlaga za konkretno delo. Planiranje je izrazito dinamična faza: izobraževalec mora predvideti, kako bo slušatelja privedel do tega, da se bo sposoben sporazumevati $v$ določenih okoliščinah. Če je na primer cilj učne enote, da bo znal slušatelj napisati prošnjo za službo, bo treba $\vee$ fazi programiranja predvideti, kako (s kakšnimi besedili, vajami, primeri, pa tudi metodami in sredstvi) bo slušatelj prišel do znanja, potrebnega za to, da bo znal $v$ danih okoliščinah napisati tako prošnjo.
Razmerje med programiranjem in planiranjem pri tečajni ali seminarski obliki jezikovnega izobraževanja

Pomembno izhodišče za selekcijo virov in izbiro metod dela je oblika, v kateri bo potekalo izobraževanje. Če bo izobraževanje potekalo v skupini, na primer kot tečaj ali seminar, bo izobraževalec $v$ prvi fazi planiranja na podlagi koncepta vsebin izbral tiste vire, ki so konkretna ponazoritev vsebin in podlaga za delo v skupini. Pri tem bo upošteval predvsem to, ali bo glavni vir izobraževanja razpoložljivo jezikovno gradivo ali ne.

- Če bo glavni vir že napisano jezikovno gradivo, bo izobraževalec pozoren predvsem na to, kje se vsebine študijskega gradivà ne ujemajo s cilji programa, in bo pripravil in izbral tiste vire, ki vsebinsko najprimerneje dopolnjujejo študijsko gradivo: primere dialogov, besedil, avdioposnetke, videodokumente, izhodišča za projektno delo ipd. Morda bo moral za katero od tem, ki v učbeniku ni zajeta, sam sestaviti gradivo: napisati besedilo ali dialog, sestaviti vaje, izbrati ali posneti av-

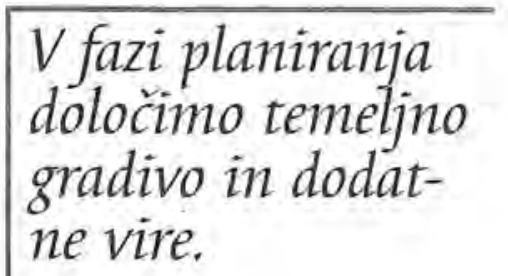
dio- in videoposnetke. Nekatera dopolnila in pojasnila bo seveda lahko predstavil tudi ustno, saj tečajna oblika to omogoča.

- Če zá delo v skupini ni mogoče uporabiti razpoložljivega študijskega gradiva, bo moral y fazi planiranja izbrati, sestaviti, napisati in/ali posneti vse gradivo, $\mathrm{s}$ katerim bo sam ali drug mentor delal v skupini.

V prvi fazi planiranja pripravi izobraževalec temeljno gradivo, ki je podlaga za doseganje ciljev programa. To temeljno gradivo (besedila, dialogi, primeri, vaje, avdio-in videoposnetki) se ne glede na obliko izvedbe, ne bo bistveno spreminjalo, saj ponazarja zastavljene teme, okoliščine in komunikacijske funkcije. Kot njegovo nadgradnjo pa bo predvidel 
še določeno število dodatnih virov, ki jih bo mentor (sam ali drug mentor) uporabil po lastni presoji glede na dinamiko $v$ skupini in razpoložljivi čas, ali pa vsaj pripravil priporočila in predloge za uporabo dodatnih virov (izhodišča za igre vlog, priporočila za izbiro in uporabo posnetkov televizijskih oddaj, časopisnih člankov, primere vaj za ponovitev slovnice ali utrjevanje besednega zaklada), ki bi lahko pomagala pri doseganju ciljev programa. Praksa jezikovnih tečajev in seminarjev se danes čedalje bolj spreminja v pravi laboratorij, saj mentorji svoje delo pogosto oblikujejo sproti, glede na zahteve in odzive v skupini, glede na aktualno družbeno in politično dogajanje: svoje delo lahko popestrijo z avdio- in videoposnetki, s članki iz revij in časopisov, vaje pripravljajo sproti, tako kot od enega do drugega srečanja zahtevajo potrebe.

\section{POMEN PLANIRANJA PRI IZOBRAŽEVANJU NA DALJAVO}

Bistveno drugačen je pristop k planiranju, če bo izobraževanje potekalo na daljavo. V tem primeru bo moral izobraževalec pripraviti tako študijsko gradivo, po katerem bo slušatelj lahko študiral sam, brez navzočnosti mentorja. Študijsko gradivo bo kot zaokrožena celota zajemalo temeljne vire in dodatno gradivo ter tudi vsa navodila in pojasnila za delo $\mathrm{z}$

Pri izobraževanju na daljavo ima študijsko gradivo osrednjo vlogo pri podajanju učnih vsebin in vzpostavljanju vzgojno-izobraževalne komunikacije. Učenje poteká brez navzoćnosti mentorja, kar pomeni, da mora študijsko gradivo zajeti vse faze andragoškega procesa in obenem prevzeti funkeije ter naloge mentorja, od motiviranja in uvajanja študenta, podajanja nove učne snovi, razlage in ponazoritve s primeri do utrjevanja in ponavljanja ter preverjanja in vrednotenja pridobljenega znanja. učnim gradivom. Faza planiranja se bo s tem na ravni učnega gradiva podaljšala $v$ izvedbo, saj bo avtor gradiva naredil projekcijo izvedbe in predvidel potek učenja. Slušatelja bo vodil pri učenju na podlagi svojih navodil in komentarjev.

Študijsko gradivo mora biti pripravljeno tako, da omogoča študentu samostojen študij brez neposredne razlage in pomoči mentorja. Ne glede na to, koliko dodátne pomoči na konzultacijah in skupinskih srečanjih bo študent deležen v okviru študijskega programa, bo večino časa preživel sam in sam napredoval skozi učno snov v študijskem gradivu.

Prav zato se mora avtor gradiva jasno zavedati, da namen gradiva ni le podajanje učne snovi, kot je to lahko pri učbenikih, ki le dopolnjujejo mentorjevo delo. V neposrednem delu mentor s svojo navzočnostjo vodi slušatelje skozi učni proces, zato je fleksibilnost izvajanja večja in se ustvari na odzivih skupine. Izjemno vlogo imajo nastop in govor, pa tudi barva glasu, kretnje, mimika, govorni presledki in poudarki, predvsem pa dinamika, ki se ustvari med mentorjem ter skupino in tudi $\mathrm{v}$ skupini. Neposredno delo $\mathrm{v}$ skupini $\mathrm{v}$ vsakem trenutku omogoča vračanje $\mathrm{k}$ nejasnim vprašanjem, dinamika se ustvarja sproti in se navezuje na dogajanje $v$ okolici, dnevne novice, novice iz medijev.

Avtorji gradiva za samostojni študij morajo dinamiko in dialog s študentom ustvariti na podlagi študijskega gradiva in tako nadomestiti mentorjevo razlago, fizično navzočnost, ton glasu, kretnje in mimiko ter vse, kar učenje $\mathrm{v}$ skupini dela privlačno in zanimivo. To lahko doseže z različnimi prijemi: z zgradbo učnih enot, jezikom in slogom pisanja, pa tudi z grafičnim oblikovanjem.

Dialoga s študentom avtor gradiva ne ustvarja samo s stilom pisanja, zgradbo in grafično obliko. Ker so študenti na daljavo odrasle osebe, mora biti podajanje snovi vpeto $\mathrm{v}$ njihovo življenje in izkušnje, sicer obvisi v zra- 
ku in je samo sebi namen. Pri odraslem potreba po pridobivanju novega znanja in spretnosti vedno izhaja iz njegovega življenja in poklicne poti, zato se mora učenje povezovati in prepletati z izkušnjami, ki jih že ima, in z okoliščinami, ki so del njegovega doživljajskega sveta in si jih lahko predstavlja. To zahteva od avtorja gradiva veliko izkušenj $\mathrm{z}$ delom $\mathrm{z}$ odraslimi in sposobnost vživljanja $\mathrm{v}$ predstave, ki jih imajo odrasli pri učenju tujih jezikov.

Avtorji izobraževalnih programov za odrasle se pri pripravi pisnega študijskega gradiva odločajo za različne rešitve. Najhitrejši način je didaktična in metodična prilagoditev razpoložljivega grádiva s posebnimi vodniki ali navodili, kako naj slušatelj študijsko gradivo uporablja. Veliko zahtevnejša, vendar najprimernejša pot pa je priprava povsem novih besedil in učbenikov.

Vsekakor mora imeti avtor gradiva jasna predstavo o ciljni skupini, ki ji je gradivo namenjeno, natančno mora poznati in opredeliti cilje programa ali predmeta, imeti predstavo o obsegu snovi, ki jo mora gradivo zajeti, predvsem pa dobro poznati organizacijo izvedbe študijskega programa na daljavo, glede načina dela mentorjev, vrste in pogostosti osebnih stikov s študenti, poteka evalvacije ipd.

\section{JEZIKOVNO PROGRAMIRANJE V RAZMERJU DO EVALVACIJE}

Evalvacija je na prvi pogled sklepna faza vsakega izobraževalnega programa, saj vsakogar zanima predvsem to, kaj je z izobraževanjem pridobil, kaj je sposoben narediti, kje bo pridobljeno znanje lahko uporabil. Dejansko pa je različno vpeta $v$ druge faze priprave in oblikovanja jezikovnih programov:

- ugotavljanje potreb temelji na čim celovitejši in natančnejši oceni jezikovnega predznanja, kar je eden temeljnih pogojev za učinkovito programiranje in planiranje;
- programiranje $v$ fazi konkretizacije in prilagajanja vsebin temelji na oceni jezikovnega predznanja, pa tudi vseh drugih okoliščin, ki jih je treba upoštevati pri izbiri tem in okoliščin, pri opredelitvi medkulturnih razsežnosti, v katere je vpeto jezikovno izobraževanje;

- v fazi planiranja se obenem s potekom izvedbe predvidijo tudi postopki in merila evalvacije;

- izvedba izobraževanja seveda pomeni tudi že izvajanje postopkov evalvacije.

V jezikovnem izobraževanju odraslih je resnično sprejemljiva le dihotomna evalvacija, saj je za odraslega lahko pomembno le to, ali je določene jezikovne spretnosti dejansko pridobil in jih je sposoben uporabiti. Če se uči tujega jezika, da bi lahko odgovarjal na dopise poslovnih partnerjev, je učenje dejansko končano šele, ko si brez večjih težav lahko dopisuje; če se uči jezika, da bi se lahko pogovarjal s svojimi prijatelji, svoj cilj Evalvacija je vklju-
cena v vse faze pri-
prave jezikovnega
programa. doseže, ko je v pogovoru sproščen in lahko brez večjih težav izrazi to, kar želi.

Razumljivo je, da je pri takem vrednotenju odločilna predvsem subjektivna posameznikova presoja: nekateri so hitro zadovoljni s svojim znanjem tujih jezikov, drugi pa nikakor in so nenehno ujeti v mehanizme samokritičnosti in nezadovoljstva. Prav pri merilih za vrednotenje lastnega znanja tujih jezikov se zavemo, kako kompleksno je področje učenja tujih jezikov in kako je povezano s posameznikovo osebnostjo, značajem, njegovo samopodobo. Za praktične, operativne osebe je znanje tujega jezika navadno le sredstvo za sporazumevanje, zato se pri komunikaciji ne obremenjujejo s slovnično korektnostjo, pomagajo si z vsemi razpoložljivimi izraznimi sredstvi (mimika, geste ipd.) in so s svojim znanjem lahko povsem zadovoljni, čeprav gre 
lahko v pogledu jezikovne korektnosti za slab jezik. Vendar so svoj namen dosegli in so $\mathrm{z}$ rezultati zadovoljni. Druga skrajnost pa so osebe, ki so preveč obremenjene $\mathrm{z}$ jezikovno korektnostjo, kar jih seveda ovira pri komunikaciji, v njej ne uživajo, se ne sprostijo, saj jim ne uspe odmisliti jezikovnih zakonitosti.

Primer za povsem različno predstavo, ki jo imajo lahko odrasli o svojem jezikovnem znanju, so lahko študenti s Primorske, ki se učijo poslovne italijanščine, in študenti, ki se učijo poslovne francoščine.* Primorci se na splošno učijo poslovne italijanščine $\mathrm{z}$ veliko samozavestjo in velikim prepričanjem o lastnem znanju, kar zelo dobro vpliva na učenje. Ker se $v$ italijanščini počutijo domače, imajo o svojem znanju in sposobnostih včasih tudi pretirano dobro in nerealno mnenje, zato hitro občutijo odpor do vsega, kar poveča zahtevnost in jih postavlja v negotov položaj, kadar česa ne vedo ali ne znajo narediti: namesto da bi bil to za njih izziv, se umaknejo in s tem zaprejo za učenje. Nasprotno pa je pri študentih, ki se učijo poslovne francoščine. Večina ima odlično predznanje, vendar na njihovo samozavest in predstavo o lastnem znanju zelo negativno vpliva pretirano poudarjanje jezikovne korektnosti, značilno za

Merila za vrednotenje lastnega znanja tujīh jezikov so povezana s posameznikovo osebnostjo. srednjo šolo. Do francoščine so razvili strahospoštovanje, ki jih ovira pri sproščeni komunikaciji, nimajo prave predstave o tem, česa so dejansko sposobni in koliko znajo, to pa je obenem tudi velika ovira pri nadaljnjem učenju. Tako se lahko zgodi, da bodo kljub trudu in dejansko velikemu znanju ostali večno nezadovoljni in imeli občutek, da premalo znajo.

Čeprav je najpomembnejše merilo pri vrednotenju jezikovnega znanja posameznikovo prepričanje o tem, ali je znanje, ki ga ima, funkcionalno ali ne, ali z njim lahko počne ti-

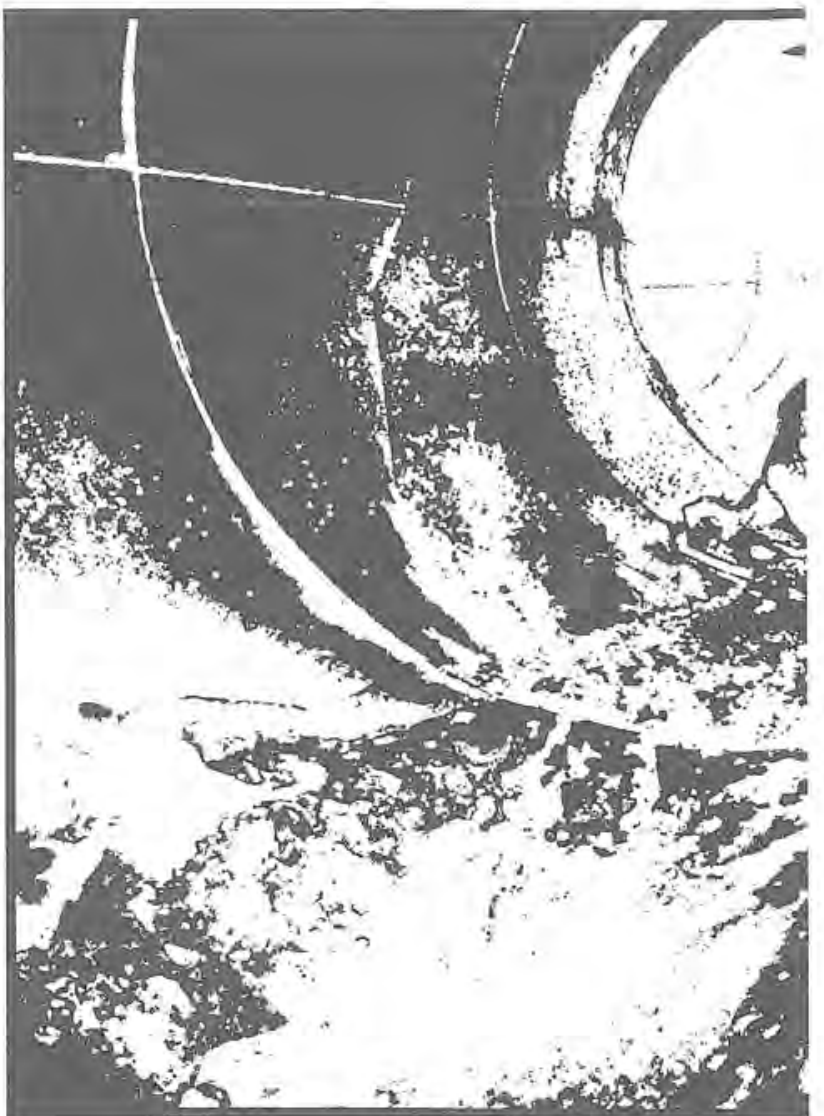

sto, kar si želi ali ne, seveda vedno obstaja tudi potreba, da se to znanje objektivno ovrednoti s testi znanja, ki pravzaprav formalizirajo

Eno od izhodišč za vrednotenje jezikovnega znanja je, kdaj se v jezikovnem izobraževanju vključi oziroma izvede vrednotenje: diagnostično vrednotenje se običajno vključi pred začetkom ali na začetku izobraževanja, da bi se ugotovilo, kakšno jezikovno predznanje ima posameznik; formativno ali sprotno vrednotenje se izvaja med potekom izobraževanja, vsakih nekaj učnih ur ali enot, in je namenjeno izbolišanju in prilagajanju izobraževalnega procesa s sprotnimi povratnimi informacijami; sumativno ali končno vrednotenje pomeni nekakšno »bilanco《 ob koncu izobraževalnega programa. 
pen načrt med izobraževalcem in slušateljem, če naj bo izobraževanje dejansko ciljno naravnan proces pridobivanja znanja: cilji izobraževanja lahko izhajajo le iz potreb in interesov tistih, ki se izobražujejo.

Jezikovno izobraževanje odraslih se od izobraževanja otrok in mladine razlikuje prav po tem, da cilj izobraževanja ni dan vnaprej, ampak se opredeli glede na vsako posamezno ciljno skupino ali slušatelja. Pri tem se seveda postavi vprašanje, kaj naj bi bil pravzaprav cilj učenja tujih jezikov. Vsekakor je to obvladovanje jezika samega, vendar to ne more biti končni cilj. Obvladovanje jezika in jezikovnih sredstev je le eden od pogojev za doseganje končnega cilja, to je uporaba jezika v določenih okoliščinah, predvsem za pisno in ustno sporazumevanje z drugimi.

Programiranje $v$ jezikovnem izobraževanju odraslih je kompleksen induktivno-deduktiven proces, ki zahteva veliko znanja, izkušenj in časa. $\mathrm{V}$ povezano celoto je namreč treba združiti jezikovne elemente (fonetika, morfologija, sintaksa itd.) in tudi kulturne ter civilizacijske elemente, pri čemer imajo pomembno vlogo številna področja, povezana $\mathrm{z}$ upotabo jezika, na primer psihologija, sociologija, filozofija, zgodovina itd. Učenje tujega jezika pomeni postopno in sistematično razvijanje sposobnosti slušnega razumevanja, branja, govorjenja in pisanja, zato je predvsem na začetnih stopnjah pri učenju in poučevanju potrebno tudi študijsko gradivo.

Razen pri zelo specifičnih ciljnih skupinah, za katere resnično ni mogoče uporabiti nobenega razpoložljivega učbenika, predavatelji tujih jezikov praviloma vzamejo za podlago učenja/poučevanja učbenik, ki je čim širše programiran. Nevarnost uporabe takega učbenika je v tem, da mentor podredi cilje programa, ki si ga je zastavil za določeno ciljno skupino, ciljem učbenika, ki so praviloma abstraktno opredeljeni in so pogosto predvsem jezikovne narave. S tem skupino slušateljev sicer pripelje do določenega jezikovnega znanja, lahko pa se zgodi, da zanemari, kakšno komunikacijsko funkcijo je imelo razvijanje jezikovnih spretnosti.

Jezikovno izobraževanje odraslih teži predvsem k manjšim skupinam z natančno, ozko opredeljenimi potrebami po znanju tujega jezika, ki zahtevajo hiter in učinkovit odgovor, Pri tem se še bolj pokaže sposobnost izobraževalca za programiranje, saj mora na podlagi lastnega znanja in izkušenj narediti koncept vsebin in projekcijo poteka izobraževanja: vsebine mora izbrati in preplesti tako, da v predvidenem času privedejo slušatelja do tega, da bo sposoben $v$ konkretnih okoliščinah pridobljeno znanje dejansko uporabljati.

Druga pomembna smer razvoja jezikovnega izobraževanja sta izobraževanje na daljavo in neformalno pridobivanje znanja tujih jezikov. Sodobna tehnologija in obstoj različnih medijev omogočajo pridobivanje znanja tujega jezika brez neposredne navzočnosti mentorja, vendar je tako izobraževanje lahko uspešno le, če temelji na jasno zastavljenih ciljih in jasnem konceptu vsebin. Programiranje je v tem primeru ključno, saj mentor s svojim neposrednim delom ne more vplivati na potek izobraževanja. Vse stopnje mora predvideti vnaprej, zato je bistveno, da je program narejen celovito in pregledno, da so vsi elementi programa osmišljeni glede na posamezne etapne cilje in glede na končni cilj izobraževanja.

Vprašanjem programiranja v jezikovnem izobraževanju odraslih še vedno posvečano premalo pozornosti. $\mathrm{Za}$ to so delno odgovorne izobraževalne ustanove, $\mathrm{ki}$ bodisi podcenjujejo pomen programiranja bodisi v programiranje niso pripravljene vlagati sredstev, saj je najdonosnejše šablonsko izvajanje enakega programa po razpoložljivem učbeniku. Žal pa pogosto tudi mentorji sami nimajo primernega znanja o principih programiranja za odrasle in zakonitostih programiranja študijskega gradiva, zato je jezikovno izobraževanje 
odraslih dostikrat še vedno odvisno od predstav, ki veljajo za učenje otrok in mladine.

\section{LITERATURA}

Cortes, Jacques (1998): Approche systémique en didactique des langues étrangeres. Colloque de Cerisy. V: Initiation à la didactique du français langue étrangere. Université de Rouen.

Coste, D. in drugi (1976): Un niveau-seuil. Strasbourg: Conseil de I'Europe.

Dunlop, I. in drugi (1991): Foreign Language Curricula: Foreign Language Education. V: Lewy, A. (ur.): The International Encyclopedia of Curriculum. Tel Aviv: Pergamon Press, str. 553-568.

Galisson, R., Coste, D. (1976): Dictionnaire de didactique des langues. Paris: Hachette.

Grosman, Meta: Poučevanje angleščine med preteklostjo in prihodnostjo. V: Grosman, M. (ur.): Učenje tujih jezikov. Uporabno jezikoslovje, 3 (1994), str. 109-119.

Hutchinson, T. in Waters, A. (1987): English for Specific Purposes. Cambridge: Cambridge University Press.

Hymes, D. (1979): On communicative competence. V : Pride, J., Holmes, J. (ur.): Sociolinguistics. New York: Penguin, str. 269-293.

Krajnc, Ana (1979-a): Andragoške zakonitosti in uěenje tujih jezikov. V: Kos, M. in drugi: Za večjo učinkovitost pouka tujih jezikov. DDU Univerzum, str. 30-63.

Krajnc, Ana (1979-b): Izobraževanje ob delu. Ljubljana: DDU Univerzum.

Krajnc, Ana (1979-c): Metode izobraževanja odraslih. Ljubljana: Delovska enotnost.

Kramsch, C. (1993): Context and Culture in Language Teaching. Oxford: Oxford University Press.

Krashen, S. D. (1981): Second Language Acquisition and Second Language Teaching. Oxford: Pergamon Press.

Lenneberg, E. H. (1967): Biological Foundations of Language. New York: Wiley.

Marentič - Požarnik, Barica (1978): Prispeyek k visokoSolski didaktiki. Ljubljana: DZS.

Marentič - Požarnik, Barica (1979): Vloga operativizacije smotrov pri (testnem) vrednotenju rezultatov pouka tujih jezikov. V: Kos, $\mathrm{M}$. in drugi: $\mathrm{Za}$ večjo učinkovitost pouka tujih jezikov. DDU Univerzum, str. 81-91.

Richterich, R. in Chancerel J.-L. (1977): Lidentification des besoins des adultes apprenant une langue étrangere. Strasbourg: Conseil de la cooperation culturelle du Conseil de l'Europe.

Richterich, René (1985): Besoins langagiers et objectifs d'apprentissage. Paris: Hachette.

Skela, Janez (1998): Metoda kot način zasnove (tuje)je- zikovnega poučevanja in učenja. V: Vestnik Društva za tuje jezike in književnosti Slovenije, let. 32, št.1-2, str. 47-66.

Svet Evrope, Council for Cultural Co-operation, Education Committee (1997): Modern Languages: Learning, Teaching, Assessment. A Common European Eramework of Reference: Draft 2 of a Framework Proposal. Strasbourg: Conseil de l'Europe.

Štrukelj, Inka (1994): Interkulturno sporazumevanje in učenje tujih jezikov. V: Grosman, M. (ur.): Učenje tujih jezikov. Uporabno jezikoslovje, st. 3, str. 51-71.

Thorndike, E. L. (1928): Adult Learning. New York.

Tilkin, Guy (2000): Travailler avec les multimédias. Bruxelles: Le Bureau d'Assistance Technique Socrates \& Jeunesse.

Tough, Allan (1972): The Adult's Learning Projectș. Toronto: OISE.

Trim, J.-L.-M. in drugi (1973): Systeme d'apprentissage des langues vivantes par les adultes. Strasbourg: Conseil de l'Europe.

Trim, John M. L. (1994): Language Teaching in the Perspecitve of Predictable Requirements of the Twentyfirst Century. V: Grosman, M. (ur.): Učenje tujih jezikov. Uporabno jezikoslovje, št. 3, str. 10-31.

Umek, Fedora (1979): Problemi usvajanja tujega jezika. $\mathrm{V}$ : Kos, M. in drugi: Za večjo učinkovitost pouka tujih jezikov. Ljubljana: DDU Univerzum, str. 30-63.

Van Ek, J-A. (1975): The Threshold Level. Strasbourg: Conseil de l'Europe.

Widdowson, H. G. (1978): Teaching language as communication. Oxford: Oxford University Press.

Widdowson, H. G. (1990): Aspects of Language Teaching. Oxford: Oxford University Press.

Wilkins, D. A. (1976): Notional Syllabuses. Oxford: Oxford University Press.

\footnotetext{
* Gre za studente Ekonomske fakultete v Ljubljani.
} 